\title{
Integration Zone Development in Bureaucratic Reform
}

\section{Pembentukan Zona Integrasi dalam Reformasi Birokrasi}

\author{
Tiyas Nur Haryani, Apriana Puspasari \\ Department of Public Administration, Faculty of Social and Political Sciences. Universitas Sebelas Maret, \\ Surakarta, Indonesia \\ email : tiyasnurharyani@staff.uns.ac.id
}

\begin{abstract}
Bureaucracy in Indonesia can be said as not optimal yet, so that there is still massive increase in corruption crime rate. Therefore, government conducts bureaucratic reform to reduce corruption practice. This research aimed to describe the implementation of bureaucratic reform in the attempt of suppressing corruption crime rate occurring in the organization of government in Indonesia. Analysis was conducted using library study providing descriptive qualitative data. Considering the data obtained from library study, it could be seen that Ministry of State Apparatuses Empowerment and Bureaucratic Reform has issued integrity zone policy in realizing corruption-free region (WBK)/ clean, catering-on bureaucratic region (WBBM).

There are some important points in integrity zone development: change management, management arrangement, human resource management arrangement, accountability reinforcement, and public service quality improvement. Integrity zone policy is expected to give implication to the reduced corruption crime in government organization
\end{abstract}

Keywords: bureaucratic reform; corruption eradication; integrity zone

\section{Abstrak}

Birokrasi di Indonesia dapat dikatakan masih belum optimal sehingga peningkatan tindak kejahattan korupsi masih masif. Maka dari itu, pemerintah melakukan reformasi birokrasi untuk mengurangi praktik korupsi. Kajian ini bertujuan mendeskripsikan pelaksanaan reformasi birokrasi dalam rangka menekan tingkat tindak pidana korupsi yang terjadi dalam penyelenggaraan pemerintahan di Indonesia. Analisis dilakukan dengan studi pustaka yang menghasilkan data kualitatif deskriptif. Berdasarkan data yang diperoleh dari studi pustaka diketahui bahwa Kemenpan RB telah mengeluarkan kebijakan zona integritas dalam mewujudkan wilayah bebas korupsi (WBK)/wilayah birokrasi bersih melayani (WBBM). Terdapat beberapa poin penting dalam pembentukan zona integritas yaitu manajemen perubahan, penataan tatalaksana, penataan manajemen sumber daya manusia, penguatan akuntabilitas, dan peningkatan kualitas pelayanan publik. Diharapkan kebijakan zona integritas memberikan implikasi dalam pengurangan tindak pidana korupsi dalam penyelenggaraan pemerintahan.

Kata Kunci: reformasi birokrasi; pemberantasan korupsi; zona integritas

\section{Introduction}

Bureaucracy can be defined as a government or often seen in executive element and public officials within. In Indonesia, governmental institution has Weberian bureaucratic characteristics: long hierarchy, procedure and written standard operation, detailed specialization, and detail specialization and career officer. Weberian bureaucracy tends create bureaucracy ignoring humanity aspect and value of organization. The negligence of humanity aspect and value leads 
to the development of mechanic working pattern or equates human with machine, bureaucrat failure to understand public issue, and discrimination against poor people (Dwiyanto, 2015). From those problems, a concept arises, called bureaucratic pathology. Types or forms of bureaucratic pathology are, among others, feudalistic, waiting for instruction or direction, loyalty to superior rather than organization, achievement-oriented culture, not supported with comprehensive technology, high cost economy and a large number of incompetent personnel (Mustafa, 2013).

Indonesian government's bureaucracy, according to public administration experts in Indonesia, has characteristics in bureaucratic pathology, among others: prioritizing the ruler's political interest rather than public interest; people have not had control yet over government bureaucracy; no political-administration dichotomy; and high corruption practice in public service (Sinambela, 2014). From those phenomena, corruption practice deserves attention as it will harm public service organization. Many corruption cases make government program delayed or failed at both national and local levels. For example, E-KTP (Electronic Identity Card) corruption case that in turn makes demographic administration and E-KTP distribution service to the public delayed when it occurs. Corruption itself is due to wish and opportunity of doing it. Bureaucratic system in Indonesia still has many weaknesses and these give the corruptors the opportunity of corrupting.

Considering the data of Corruption Perception Index (CPI) of 2018, Indonesia is on the $38^{\text {th }}$ rank out of 100 and $89^{\text {th }}$ out of 180 states (International, 2019). In measuring Corruption Perception Index (CPI), the closer the number to 100, the better is the Corruption Perception Index. Actually Indonesia's position has increased from 37 in 2017 to 96 in 2018 (International, 2019). It indicates the decreased number of corruption case occurring in Indonesia. However, Indonesian government still should pass through a long way to eradicate all corruptors because Indonesian Corruption Perception Index is only 38 out of 100. Corruption occurs due to, among others: supervision, accountability and management, counter-opinion in justice institution, so that there has never been encounter between condemnation and liberation (Haryani, 2017).

One of attempts to be taken to eradicate corruption in Indonesia is to reform bureaucracy. The objective of reform is generally to bring the good governance into reality, supported with professional state organization, corruption-, collusion-, and nepotism-free, and to improve public service thereby achieving first-rate service (Sedarmayanti, 2009). In addition to good governance, bureaucratic reform also has mission, to change mindset and cultural set of the bureaucrats (Mustafa, 2013). If mindset and cultural set of corruption can be changed, a bureaucrat's potential wish to do corruption can be suppressed. If government can perform bureaucratic reform well, and coupled with the corruption handling or eradication attempt taken by KPK, corruption problem in Indonesia is expected to be resolved well.

Previous studies have been conducted on bureaucratic reform by some academicians and practitioners. In 2018 a study has been conducted on bureaucratic reform in Indonesia in public administration perspective (Haning, 2018). Another study has also been conducted on opportunity and threat in bureaucratic reform in Indonesia (Yusriadi, 2018). In addition, a study on performance accountability system has been conducted (Hidayat, 2016) and so has a study 
on implementation procedure reform (Ahmad, 2016). This study focuses on bureaucratic reform aspect conducted by Indonesian government in corruption eradication. The author will study it from Minister of Administrative and Bureaucratic Reform's Regulation Number 52 of 2014 about Guidelines of Integrity Zone Development toward Corruption-Free Region and Clean and Catering-on Bureaucratic Region in Governmental Institution Environment.

\section{Method}

This study was a descriptive qualitative research. This research wants to address bureaucratic in Indonesia in corruption eradication comprehensively, including complexity within it. The author explained it again in descriptive form corresponding to data analysis conducted. Data collection was conducted using library or document study. Documentation study is a technique of collecting data using document or written/printed materials/recordings of event relevant to the topic of study. The document intended can be in hardcopy or softcopy (Sarosa, 2012). Document the author used derived from Minister of Administrative and Bureaucratic Reform's Regulation Number 52 of 2014 about Guidelines of Integrity Zone Development toward Corruption-Free Region and Clean and Catering-on Bureaucratic Region in Governmental Institution Environment, Republic of Indonesia's Law Number 14 of 2008 about Public Information Transparency and journals on corruption eradication topic.

\section{Result and Discussion}

\section{Corruption}

Corruption is the behavior of some public sector officials, either politicians or civil servants, in which they enrich themselves or people around them unlawfully, by abusing public power entrusted to them (Suradi, 2014). Corruption is also explained involves fund fraud, stealing of corporate or state property through such practices as bribery, exploitation, or intervening with decision. Corruption, according to Law Number 2 of 2001 about Corruption Crime as the amendment to Law Number 31 of 1999, is every individual unlawfully commit a deed to enrich him/her self or others or a corporation that can harm the state finance or economy. There are three important elements making an individual doing corruption (in the book called fraud): perceived pressure, perceived opportunity, and some way to rationalize the fraud as acceptable (Suradi, 2014). The corruption action or behavior process in public service activities can be divided into (Anggraeni, 2014):

a. External corruption, in which third party is involved. It is more frequently due to authority owned by an individual very influential in the public service running, whether in releasing permit or certain recommendation letter. The one with such 
authority will require certain return in the form of service to accelerate public service or material.

b. Bribery, other individuals are also involved in this action. Bribery often occurs in institution functioning and serving to provide licensing service, recommendation, and etc. Bribers often look for intermediary to facilitate their affairs with monetary reward or usually called bribe that can influence objectivity in decision making. Finally, the decision will be partial or favorable to the bribers.

Corruption can result in governance dysfunction with the lowered effectiveness of public service and bureaucratic distortion (Umam, 2014). Corruption is also called pathology in public bureaucracy, the characteristics of which are like cancerous cell that can spread to other units if it is left to develop. Corruption-related problem is not new in Indonesia; even corruptive behavior has been existing since colonial time within society, particularly among land owners cooperating with East Indie government. The exclusiveness priyayis accustomed to submit gift to colonials to smoothen their and family business interest eventually became culture and consensus, in which it was considered as gratitude only (Mapuasasri, 2018). Compared with today situation, description of tribute behavior to the rulers is a form of gratification. The demand for law enforcement in corruption case begins to increase in the end period of President Soeharto's reign; development does not exert trickle down effect putatively today due to the occurrence of corruption in government environment. Corruption in government and corporate body is no longer conducted individually but it has been done in group (Mapuasasri, 2018). Corruption should be anticipated from early education of children in order to prevent it from being habit and working and organizational culture.

2. Bureaucratic Reform

Reform is a systematic, integrated, and comprehensive endeavoring process to bring good governance into reality (Sedarmayanti, 2009). Meanwhile, bureaucracy is a government organization system implemented by civil servants based on legislation (Sedarmayanti, 2009). Thus, it can be concluded that bureaucratic reform is a systematic, integrated, efficient, effective, professional, and comprehensive endeavoring process to change the state organization system into the better one corresponding to the legislation (Hapsari, 2019). The goals of bureaucratic reform are the realization of a professional, neutral, and prosperous bureaucracy; the capability of positioning the self as state and community servants in order to realize better public service; the realization of proportional, flexible, effective, and efficient governmental institution in both central and local government environments; the realization of fast, noncomplicated, and easy (public service) management corresponding to the public need (Sedarmayanti, 2009). Bureaucratic reform also becomes a big hope in supporting the successful development, because the bureaucracy's duty and function frequently pertain to public policy and service (Sulistiadi, 2019). 
Bureaucracy can be presupposed to be a market confronting demand and offer in corruption action. In bureaucratic reform, there is an Integrity Zone development program aiming to eradicate corruption in bureaucratic body. This integrity zone development focuses on the implementation of Change Management, Management arrangement, Human Resource Management System Arrangement, Supervision Reinforcement, Performance Accountability Reinforcement, and concrete Public Service Quality Improvement programs as leveraging components. Leveraging component is the one determining the achievement of targeted output in Integrity Zone development. Furthermore, it is this component that is used in this study, because the bureaucratic implementation is governed in legislation, including bureaucratic reform implementation. This leveraging component of Integrity Zone has been governed in Minister of Administrative and Bureaucratic Reform's Regulation Number 52 of 2014 about Guidelines of Integrity Zone Development toward Corruption-Free Region and Clean and Catering-on Bureaucratic Region in Governmental Institution Environment. Integrity Zone, according to the Minister of Administrative and Bureaucratic Reform's Regulation Number 52 of 2014, is a predicate given to government institution in which its leader and lines are committed to realize WBK/WBBM through bureaucratic reform, particularly in the terms of corruption prevention and public service quality improvement (Hapsari, 2019).

3. Integrity Zone Development as Bureaucratic Reform form

In Indonesia, there is a ministry responsible specifically for bureaucratic reform, i.e. Ministry of Administrative and Bureaucratic Reform of Republic of Indonesia (Kemenpan RB). Kemenpan RB stipulates the Minister of Administrative and Bureaucratic Reform's Regulation Number 52 of 2014 as a measure to fight against corruption in Indonesian bureaucracy. This regulation (Permen) contains the Guidelines of Integrity Zone development toward Corruption-Free Region (WBK) and Clean and Catering-on Bureaucratic Region (WBBM) in Governmental Institution. Integrity zone is a predicate given to governmental institution, the leader and lines of which are committed to realize WBK/WBBM. The launching of Integrity Zone development as the means of Bureaucratic Reform requires a success in building clean service without an element of the violation provision harming the society (Nugroho, 2016). The main target to be achieved in Integrity Zone development is the realization of clean corruption-, collusion-, and nepotism-free government and of improved public service quality. In Integrity Zone, all lines affiliated in the development are expected to actually implement Bureaucratic Reform sustainably (Nugroho, 2016). Leveraging components of Integrity Zone becoming the determinant of the achievement of Integrity Zone development output targeted are as follows:

\section{a. Change Management}

The change management intended in Permenpan RB Number 52 of 2014 aims to change the systematization and consistency of working mechanism, mindset and cultural set built into the better one corresponding to the objective and target of integrity zone development. One of important points in the change management is the change of mindset and cultural set in the bureaucratic human resource. Considering 
the finding of previous study conducted by Haning (2018), it can be seen that bureaucratic reform occurring in Indonesia runs very slowly. It is primarily due to the difficulty of changing one bureaucratic element, HR aspect. The mindset of HR existing in bureaucracy has been owned since a long time ago, so that HR accepts the change difficultly. An attempt taken by government to reform mindset is to promote mental revolution pioneered by President Joko Widodo. Based on information acquired from PKP Team of Ministry of Communication and Informatics (2014), three (3) basic attempts need to be taken by individual ministries/institutions $(\mathrm{K} / \mathrm{L})$ in mental revolution implementation. They are: to create synergy, to build issue management, and to reinforce the capacity of state apparatuses. These attempts are intended to build the integrity of Ministries/Institutions (K/L).

b. Management arrangement

Permenpan RB Number 52 of 2014 mentions that the management arrangement is intended to improve the efficiency and effectiveness of clear, effective, efficient, and measurable working system, process, and procedure in Integrity Zone toward Corruption-Free Region (WBK) and Clean and Catering-on Bureaucratic Region (WBBM). There are three basic points in the management arrangement: Standard Operating Procedure (SOP) of main activities, E-Office, and public information transparency. The development of SOP should be supported with process business mapping representing the effective and efficient working relationship order between organizational units in individual ministry environments (Presidential Regulation Number 7 of 2015 about State Ministry Organization). As such, it will result in integrated SOP and facilitate its implementation (Ahmad, 2016). SOP arranged should be evaluated and monitored to find out the extent to which it is referred to in the implementation of daily duty and function.

Utilizing information technology is an attempt taken to connect government to the public in delivering better service (Yusriadi, 2018). The implementation of government today has been facilitated by online system. It is in contrast to that in the past, when people should be in queue to deal get a document and should go to many places to get one type of document only. Now people can access government's various services from home with internet only. This online public service system is more effective as it can reduce service implementation procedure usually too complicated and it is more efficient because government needs personnel to operate the system only. In this modernization era, public service office in many institutions or in regions has utilized information technology or called e-goverment.

Government should also attempt the information transparency in the presence of Law Number 14 of 2008 about Information Transparency. Article 7 of the Law states that Public Body should obligatorily provide public information accurately, correctly and not deceptively. There are two types of public information to be announced or provided by Public Body as mentioned in Article 9. Firstly, information should be announced periodically, such as information related to Public Body, information related to Public Body's activity and performance, financial statement, and other information governed in legislation. Secondly, information announced suddenly is the one that can 
threat many peoples' life. The information is accessible to the public through the official website of ministry, institution, office, and city government throughout Indonesia. Some city governments specifically develop application to facilitate the people to acquire information such as Solo Destination application belonging to Surakarta City Government. In this one application, there are various information around Surakarta City from tourism, culinary, e-tax, licensing, public transportation, public facilities, law enforcement, Solo City's virtual tour, child radio, dashboard, public info, and public complaint.

c. The arrangement of HR Management System

The arrangement of HR management system aims to improve HR professionalism of apparatus in Integrity Zone toward Corruption-Free Region (WBK) and Clean and Catering-on Bureaucratic Region (WBBM) (Permenpan RB Number 52 of 2014). To recruit the quality personnel or Human Resource, government has applied new system in recruiting candidate civil servants (CPNS). Formerly, CPNS recruitment was conducted offline so that many frauds still occur. The fraud most frequently occurring is related to position filling. Therefore, government changes CPNS recruitment system from offline into online one called Computer Assisted Test (CAT). CAT (Computer Assisted Test), according to BKN (National Civil Service Agency), is defined as a computer-aided selecting method used to obtain minimum standard of basic competence to CPNS applicants (https://jogja.tribunnews.com). CAT can reduce the risk of position filling-related bribery because all selection activities have been done by system.

Other matters needing attention in the arrangement of human resource management are internal mutation, individual performance assignment, discipline/ethical code/civil servant behavioral code regulation enforcement, and civil service information system. Internal mutation is conducted to reduce saturation with the job that can lower the civil servants' performance. For the performance to be maintained and/or improved, individual performance should also b specified to enable the civil servants to find out their performance and to improve the poor performance. The most important attempt to be taken to prevent the civil servants from violating or from abusing power is to enforce civil servant discipline/ethical code/behavioral code. There are two basic regulations governing State Civil Apparatus or Civil Servants: Law Number 5 of 2014 about State Civil Apparatus and Government Regulation Number 53 of 2010 about Civil Servant Discipline,

\section{d. Accountability Reinforcement}

The objective of accountability reinforcement mentioned in Permenpan RB Number 52 of 2014 is to realize a governmental institution's obligation to be accountable for the successful/the failed program implementation and activities in achieving the mission and vision of organization. Simply, it can be described that the good implementation of performance accountability is as series of management cycle, including: 1. Planning performance and determining the performance measure; 2. 
Setting up the targeted performance; 3) setting up program/activities compatible to the achievement of performance specified; 4. Budgeting to achieve performance; 5 . Implementing program/activity to be done to achieve the performance; 6 . Measuring and reporting their successful performance to be feedback to the sustainable improvement of government's performance management (Hidayat, 2016). Considering the annual performance plan and budget specified, governmental institution then develops Performance Agreement as the manifestation of performance agreement or performance contract between the trustee and the trusted, concerning the measurable target of performance. In the end of fiscal year, having implemented entire actual performance, governmental institution should be accountable for the measurable performance achievement through Performance Report, and accountable for financial affairs through financial statement. Performance Report, in addition to be a performance accountability instrument, also serves as the means of getting feedback in the attempt of improving the next planning process or the performance (Hidayat, 2016).

\section{e. Public Service Quality Improvement}

The reinforcement of public service quality mentioned in Permenpan RB Number 52 of 204 is an attempt of improving public service quality and innovation in individual government institutions periodically according to public need and expectation. Many innovations have been made by government in improving the public service quality. One of them is to providing One-Stop Integrated Service (PTSP). One-Stop Integrated Service (PTSP) is governed in Presidential Regulation Number 97 of 2014 explaining that PTSP is an integrated service in one process unity starting with completing the service product through on gate. The Perpres (Presidential Regulation) also explains the objectives of PTSP implementation, i.e. to give protection and law certainty to the public, to shorten the service process, to realize a fast, easy, cheap, transparent, certain, and affordable service process, and to get the service closer to the public and to give broader service to the public. Some innovations have also been made in public service by utilizing technology, e.g. e-pajak (electronic tax), e-retribusi (electronic retribution), and etc. This innovation is intended to avoid the leakage of tax payment and retribution. These online tax payment and retribution are conducted directly by the corresponding one without intermediary, and thus the money comes into the state's cash directly. In addition, online payment also facilitates the people to pay as it can be done anywhere and anytime.

\section{Conclusion}

Bureaucratic reform in Indonesia is the measure taken by government to eradicate corruption crime in the organization of public service and government work. Ministry of Administrative and Bureaucratic Reform institutes a program to develop integrity zone in realizing Corruption-Free Region (WBK) and Clean and Catering-on Bureaucratic Region (WBBM). There are four leveraging components in this implementation of integrity development: change management, management arrangement, human resource management arrangement, 
accountability reinforcement, and public service quality improvement. The change management is conducted by changing the ASN (Civil Servant)'s mindset through mental revolution program. Management arrangement is accomplished through reforming complicated bureaucratic system by utilizing technology. HR management arrangement is conducted earlier, in the civil servant recruitment using Computer Assisted Test (CAT) system. In addition, the arrangement of HR management is also conducted by organizing internal mutation, setting up individual performance, enforcing servants' discipline/ethical code/behavioral code, and civil service information system. The point of accountability reinforcement is the form of accountability from either successful or failed program implementation in the form of performance report and financial accountability in the form of financial statement. Finally, the improvement of public service quality is conducted through One-Stop integrated Service innovation and online tax and retribution payment. Bureaucratic reform can also be accomplished through institutional restructuring, joint accountability, bureaucratic role redefinition, building transparent bureaucracy, and controlling discretion use. Institutional restructuring is necessary to remove elaborate, complicate, and fragmented bureaucracy. In addition, bureaucracy should change the subordinate-superior relation formerly tends more to be individual and formal relation into the collegial one based on group accountability. Bureaucracy should also reconstruct the role of bureaucrats formerly prioritizing more power and acting just like the ruler into the one prioritizing the public need and serving as service agent. For the bureaucratic implementation to be supervised directly by the public, information transparency is required. Bureaucrats can utilize the non-transparent bureaucracy to take discretion not declared transparently regarding purpose, goal, and for whom the discretion is. As a result, the discretion authority often arises to be the cause of corruption. Therefore, the use of discretion should be controlled.

\section{References}

Ahmad, Y. A. (2016). Tepat Proses dan Prosedur : Kunci Sukses Reformasi Tata Laksana. Jurnal Pendayagunaan Aparatur Negara, $V l(\mathrm{Vl})$.

Anggraeni, T. D. (2014). Menciptakan Sistem Pelayanan Publik yang Baik : Strategi Reformasi Birokrasi Dalam Pemberantasan Korupsi. Jurnal RechtsVending, 3(3, Desember).

Dwiyanto, A. (2015). Reformasi Birokrasi Kontekstual. Gadjah Mada University Press.

Haning, M. T. (2018). Reformasi Birokrasi di Indonesia: Tinjauan Dari Perspektif Administrasi Publik. JAKPP : Jurnal Analisis Kebijakan Dan Pelayanan Publik, 4(1, Juni).

Hapsari, J. H. P. B. P. P. (2019). IMPLEMENTASI PEMBANGUNAN ZONA INTEGRITAS MENUJU WILAYAH BEBAS DARI KORUPSI DAN WILAYAH BIROKRASI BERSIH DAN MELAYANI DI BBWS PEMALI JUANA SEMARANG. DIALOGUE JURNAL ILMU ADMINISTRASI PUBLIK,,$(1)$.

Haryani, T. N. dan O. H. N. (2017). Menakar Kapasitas Sumber Daya Manusia Aparatur Sipil Negara dalam Mewujudkan Penyelenggaraan Pelayanan Publik yang Berkualitas (Studi pada Nilai Anti Korupsi). Habitus: Jurnal Pendidikan, Sosiologi, Dan Antropologi, (1).

Hidayat, S. dan C. A. S. (2016). Evaluasi Implementasi Sistem Akuntabilitas Kinerja Instansi 
Pemerintah Daerah Kabupaten/Kota. Jurnal Pendayagunaan Aparatur Negara, VI(VI).

International, T. (2019). Corruption Perceptions Index 2018.

https://www.transparency.org/cpi2018

Mapuasasri, S. A. dan H. M. (2018). Korupsi Berjamaah: Konsensus Sosial atas Gratifikasi dan Suap. Integritas, 4(2).

Mustafa, D. (2013). Birokrasi Pemerintah. ALFABETA.

Nugroho, R. (2016). OPTIMALISASI PEMBANGUNAN ZONA INTEGRITAS MENUJU WILAYAH BEBAS KORUPSI (WBK) DAN WILAYAH BIROKRASI BERSIH MELAYANI (WBBM) PADA LEMBAGA PELAYANAN PERTANAHAN. Jurnal Pertahanan, 6(2, November).

Sarosa, S. (2012). Penelitian Kualitatif Dasar dasar. PT Indeks.

Sedarmayanti. (2009). Reformasi Administrasi Publik, Reformasi Birokrasi, dan Kepemimpinan Masa Depan: Mewujudkan Pelayanan Prima dan Kepemerintahan yang Baik. Refika Aditama.

Sinambela, L. P. (2014). Reformasi Pelayanan Publik: Teori, Kebijakan, dan Implementasi. PT Bumi Aksara.

Sulistiadi, D. W. (2019). EFEKTIVITAS PENILAIAN MANDIRI EVALUASI MENUJU WILAYAH BEBAS DARI KORUPSI/WILAYAH BIROKRASI BERSIH MELAYANI DI KEMENTERIAN KESEHATAN DALAM RANGKA PELAKSANAAN KEBIJAKAN REFORMASI BIROKRASI. JURNAL KEBIJAKAN KESEHATAN INDONESIA : JKKI, 9(3 September).

Suradi. (2014). Pendidikan Korupsi. Gava Media.

Umam, A. K. (2014). ISLAM, KORUPSI DAN GOOD GOVERNANCE DI NEGARA-NEGARA ISLAM. Al Ahkam Jurnal Pemikiran Islam, 24(2).

Yusriadi. (2018). Reformasi Birokrasi Indonesia: Peluang dan Hambatan. Jurnal Administrasi Publik (Public Administration Journal), 8(2). 